\title{
Climate-forced seasonal mismatch between the hatching of rhinoceros auklets and the availability of anchovy
}

\author{
Yutaka Watanuki ${ }^{1, *}$, Motohiro Ito ${ }^{1}$, Tomohiro Deguchi ${ }^{2}$, Shoshiro Minobe ${ }^{3}$ \\ ${ }^{1}$ Graduate School of Fisheries Sciences, Hokkaido University, Minato-cho 3-1-1, Hakodate 041-8611, Japan \\ ${ }^{2}$ Yamashina Institute for Ornithology, Takanoyama 115, Abiko, Chiba 270-1145, Japan \\ ${ }^{3}$ Graduate School of Sciences, Hokkaido University, Kit-10 Nishi-8, Kita-ku, Sapporo 060-0810, Japan
}

\begin{abstract}
Predator-prey relationships are key to understanding complex marine ecosystem dynamics. The match-mismatch hypothesis posits that predators time energy-intensive activities, such as reproduction, to periods of high food availability. However, predators may be constrained by various ecological or physiological processes, leading to mistimed activities relative to prey availability. We investigated inter-annual variation in the timing of breeding for a piscivorous seabird (rhinoceros auklet Cerorhinca monocerata) in relation to availability of a preferred prey item, Japanese anchovy Engraulis japonicus, using data collected over 18 yr between 1984 and 2006 at Teuri Island in the northern Japan Sea. Our primary goals were (1) to identify the climatic factors that affect the seabirds' timing of breeding, proxied by hatching date, and anchovy seasonal availability, and (2) to quantify the fitness effects of predator-prey matches and mismatches relative to climate variability. Hatching date was later in years with lower spring air temperatures. Auklets switched their feeding from sandlance and juvenile greenling to anchovy when it was transported into the birds' foraging range with the seasonal northern expansion of $13^{\circ} \mathrm{C}$ warm water from the south. The mismatch between hatching date and the period of high anchovy availability was most pronounced when spring air temperatures were warm, and there was a weak Tsushima (warm) Current. Spring air temperature was influenced by spring atmospheric pressure gradients in the Arctic and northern Eurasia, which drive the east Asian winter monsoon, whereas timing of the Tsushima warm water expansion was influenced by winter surface pressures over the western North Pacific. Chick growth rates, mass at fledging, and overall fledging success (fitness) were lower during mismatch years when the auklets fed less on anchovy. The auklets were constrained to adjust hatching date because the seasonal mismatch appeared to be driven by independent and unpredictable surface pressure patterns.
\end{abstract}

KEY WORDS: Climate change $\cdot$ Match-mismatch $\cdot$ Seabirds $\cdot$ Atmospheric pressure systems Reproductive consequences

\section{INTRODUCTION}

Most species of birds mate, lay eggs, hatch, grow, and migrate during specific, well-defined periods of the year when physical and biological conditions (e.g. light, temperature, precipitation, prey availability) are suitable for these activities (Lack 1968, Stenseth \& Mysterud 2002). Climate fluctuations are known to shift these specific periods ('phenological' shifts), sometimes differently across species (Stenseth \& Mysterud 2002, Visser \& Both 2005). Different phenological responses in species of varying trophic levels may lead to mismatches between functionally different components of an ecosystem (e.g. prey and predator), with important effects on ecological structure and function (Stenseth et al. 2002).

Terrestrial birds provide a good example. As these birds have high energy requirements during the chickrearing period (Drent \& Daan 1980), parents time the 
onset of breeding so that the availability of prey is highest during this period. Many bird species have advanced their laying date in response to the increase in spring air temperatures over the past 2 decades (Crick et al. 1997, Visser et al. 2003), although this response varies among species and regions. Weak responses in migrating (Both et al. 2005) and predatory (Both et al. 2009) birds have caused seasonal mismatches between the birds and their prey, which has led in some cases to population declines (Both et al. 2006).

In marine ecosystems, upper trophic level predators demonstrate high metabolic needs during breeding. Inter-annual variation in the abundance and distribution of prey may similarly result in mismatches between food availability and predator needs, with substantial reproductive consequences (Anderson \& Piatt 1999, Hunt \& Stabeno 2002, Platt et al. 2003, Edwards \& Richardson 2004). In seabirds, the date of arrival at the breeding area or the egg-laying date depends on inter-annual variation in ocean climate (Durant et al. 2004, Frederiksen et al. 2004, Barbraud \& Weimerskirch 2006, Schroeder et al. 2009 this Theme Section). Biological determinants of breeding data have also been established. In relation to a change in the date of zooplankton peak availability, there is a seasonal mismatch between zooplanktivorous Cassin's auklets Ptychoramphus aleuticus and their prey (Bertram et al. 2001, Hipfner 2008) in British Columbia, Canada. However, parent birds of the same species in California (Abraham \& Sydeman 2004) and other seabird species (e.g. tufted puffins Fratercula cirrhata, Gjerdrum et al. 2003; kittiwakes Rissa tridactyla and common murres Uria aalge, Frederiksen et al. 2004) may be able to adjust hatching dates so that peak prey availability coincides with the chick-rearing period.

To understand the impacts of climate change on seabird populations, it is important to identify factors affecting the onset of breeding, the timing of peak prey availability, and factors constraining adjustment. In the North Pacific, the widely distributed rhinoceros auklet Cerorhinca monocerata provides an excellent system to test ideas pertaining to climate change and the match-mismatch hypothesis. The auklets feed mainly on epipelagic fishes within a limited range from the colony (Gaston \& Jones 1998, Thayer et al. 2008). The relationships between ocean climate, food habits, and reproductive success of rhinoceros auklets differ among British Columbia (Bertram et al. 2001, Hedd et al. 2006), California (Thayer and Sydeman 2007), and Japan (Deguchi et al. 2004a), but the influence of ocean climate on the match or mismatch of predator and prey has yet to be investigated.

Using data collected over 18 years between 1984 and 2006 at Teuri Island in the Japan Sea (Fig. 1), we identified local climate factors affecting the hatching date

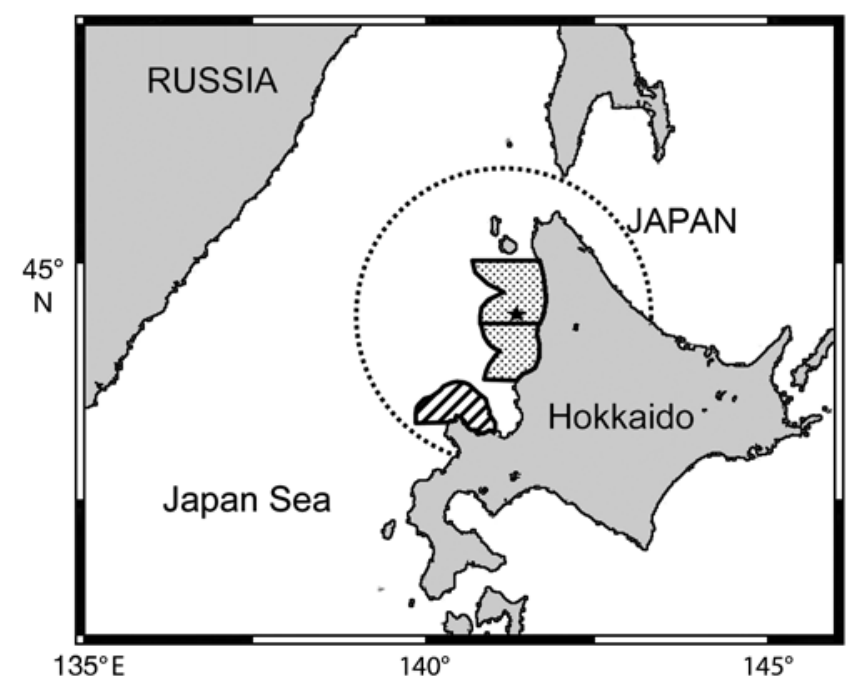

Fig. 1. Teuri Island (star), the area where local sea surface temperature (LSST) was measured (stippled), and the area where SST at the southern edge of the foraging range of auklets was measured (hatched). Potential foraging range of rhinoceros auklets from Teuri Island (Kato et al. 2003, $164 \mathrm{~km}$ ) is within the dotted line

of rhinoceros auklets and the period of peak availability of their prey, and examined the effects of a seasonal mismatch between these dates on breeding success. To illustrate the relationships between local ocean climate and global climate, we examined the linkage between surface atmospheric pressure patterns in the Arctic and northwestern Pacific that drive wind and water currents in the Japan Sea (Minobe et al. 2004). At Teuri Island, when summer sea surface temperature (SST) within about $100 \mathrm{~km}$ of the colony is high, the auklets switch prey from energy-poor age-0 sandlance Ammodytes personatus and age-0 greenling Pleurogrammus azonus to the energy-rich anchovy earlier in the year, and chick growth is faster (Takahashi et al. 2001, Deguchi et al. 2004a). Therefore, we investigated specifically (1) how the local climate factors such as air temperature and SST affected auklet hatch date and the date of prey-switching to anchovy, (2) the degree of mismatch between these 2 dates and the effects of mismatch on the mass proportion of anchovy in the diet, (3) the link between the sea surface pressure pattern over the Northern Hemisphere and local climate factors, and (4) the effects of the proportion of anchovy in the diet of chicks on chick growth and fledging success.

\section{MATERIALS AND METHODS}

Field work. Data were collected over 18 yr at Teuri

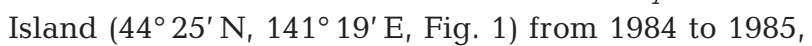
in 1987, and from 1992 to 2006. The breeding perfor- 
mance of birds in natural burrows and artificial nest boxes (Kuroki et al. 1998) was studied. Nests were checked between 16:00 and 18:00 h every 3 to $5 \mathrm{~d}$ to determine the hatching date and mass of chicks. Between 10 and 66 nests with hatchlings were monitored each year (Deguchi et al. 2004b). When newly hatched chicks were found, these were assumed to have hatched at the midpoint of the interval between the nest censuses. Chicks were weighed with a Pesola spring balance to the nearest $5 \mathrm{~g}$. The growth rate of each chick was defined as a slope of the linear regression line of chick mass (g) against age (d) for chicks 5 to 20 d old (Takahashi et al. 2001). Chicks that disappeared from the nest after attaining the age of $40 \mathrm{~d}$ were considered to have fledged.

Diets were sampled by capturing birds with food loads along a road in the colony within $\sim 100 \mathrm{~m}$ of the nest-monitoring site. Birds were captured as they landed between 19:00 and 22:00 h with either a swooping net or by hand. Sampling was initiated as soon as birds were observed carrying fish to nest sites, typically from mid-May to early June. Diet was sampled once every 2 wk during 1984 to 1995 (except for the years 1986, 1988 to 1991), every 3 to 5 d during 1996 to 2001 and every week during 2002 to 2006. Each food load was put into a separate bag, which was brought back to the laboratory for identification. Fish species were identified using a key by Amaoka et al. (1995) and weighed to the nearest $0.1 \mathrm{~g}$ with an electronic balance, and fork length was measured to the nearest $1 \mathrm{~mm}$. On each sampling date, 3 to 76 food loads were collected, for a total of 64 to 226 food loads each year.

To determine the ocean climate, proxied by SST, in the areas where rhinoceros auklets feed on anchovy, we recorded the diving behavior of the parents and water temperature at the feeding site by using birdborne data-loggers in 2006. With quick-set glue and plastic netting, we attached $2.7 \mathrm{~g}$ data-loggers (Cefas G5, CTL), which recorded depth (0.1 $\mathrm{m}$ accuracy) and temperature $\left(0.1^{\circ} \mathrm{C}\right.$ accuracy $)$ at $3 \mathrm{~s}$ intervals for up to $8 \mathrm{~d}$, to 5 birds that were rearing chicks in artificial nests (Kuroki et al. 2003). The loggers were retrieved 7 to $10 \mathrm{~d}$ after deployment. To identify the species of prey brought back to the chicks by these birds, we videotaped the nest chambers of the same birds using a video camera and infrared light ( $\mathrm{SH}-6 \mathrm{~B}$, Wireless Tsukamoto). The resulting video images were clear enough to identify the fish species.

Determination of the date of prey-switching. Japanese anchovy migrate northward with the Tsushima Current, which flows from the southern Japan Sea during the spring and summer (Naganuma 2000). We defined the date of prey-switching to anchovy (SWITCH) as the date when $50 \%$ of rhinoceros auklets brought anchovy in their food loads. To determine
SWITCH, we used logistic regression (SPSS v.14), where an assignment of each food load ('anchovy' $=1$ or 'non-anchovy' $=0$ ) was the dependent variable and the day of year was the independent variable. Most food loads $(98 \%)$ contained only a single species of fish. Of the other $2 \%$, those whose mass was more than $50 \%$ anchovy were considered anchovy food loads and the others were considered non-anchovy food loads.

We verified this analysis using detailed data from 2006. Between 30 May and 30 June in 2006, prey species of fish carried by auklets (8 to 57 birds night ${ }^{-1}$ ) were identified by direct observation every evening (19:30 to $20: 30 \mathrm{~h}$ ) at an observation site (about $5 \times 5 \mathrm{~m}$ ) beside the nest-monitoring site. Rhinoceros auklets brought age-0 sandlance, age-0 greenling, and herring Clupea pallasi before mid-June, but food loads were composed mostly of anchovy after that (Fig. 2a). The prey-switching occurred within $1 \mathrm{wk}$. Using the logistic regression approach $(\mathrm{p}<0.001)$, SWITCH was found to occur on 21 June (day of year 172; Fig. 2a). According to the direct daily observation of birds with food loads, SWITCH occurred on 18 June (Fig. 2b); these data are in agreement.

SST and anchovy distribution. Rhinoceros auklets perform several dive bouts, each consisting of 3 to 212 consecutive dives, during daylight hours each day. In the evening, they stop diving and bring food back to the chicks (Kuroki et al. 2003). The SST recorded during the final dive bout of each day should be that of the water where the auklet obtains the fish in each food load. However, the temperature sensor has a slow response time (i.e. the time needed to reach $66 \%$ of the temperature difference; $28 \mathrm{~s}$ ), making direct measurement of SST problematic. Therefore, we excluded temperature records during the first and the second dives of each bout, because these might reflect the air temperature (Watanuki et al. 2001). We averaged the temperatures recorded at the start and at the end of each dive, then defined the grand average across all dives during each dive bout as the 'SST.' To check the reliability of this procedure, we simulated 10 dives as 1 dive bout and repeated the simulation 3 times. In each dive, the data-logger was submerged in $13^{\circ} \mathrm{C}$ water for $10 \mathrm{~s}$ (descent in the 'surface layer'), then in $11^{\circ} \mathrm{C}$ water for $10 \mathrm{~s}$ (foraging in the 'deeper layer'), again in $13^{\circ} \mathrm{C}$ water for $10 \mathrm{~s}$ again (ascent in the 'surface layer'), and then placed in the air at $23^{\circ} \mathrm{C}$ for 10 to $60 \mathrm{~s}$ (postdive surface time). The ' $\mathrm{SST}^{\prime}$ range of the 3 simulated dive bouts was 12.5 to $13.0^{\circ} \mathrm{C}$, which is the same (within $0.5^{\circ} \mathrm{C}$ of accuracy) as the water temperature of the 'surface layer'. Thus, the grand mean of the temperatures recorded at the start and end of each dive during dive bouts including more than 10 dives gave a reasonable approximation of the SST where the birds were diving. 

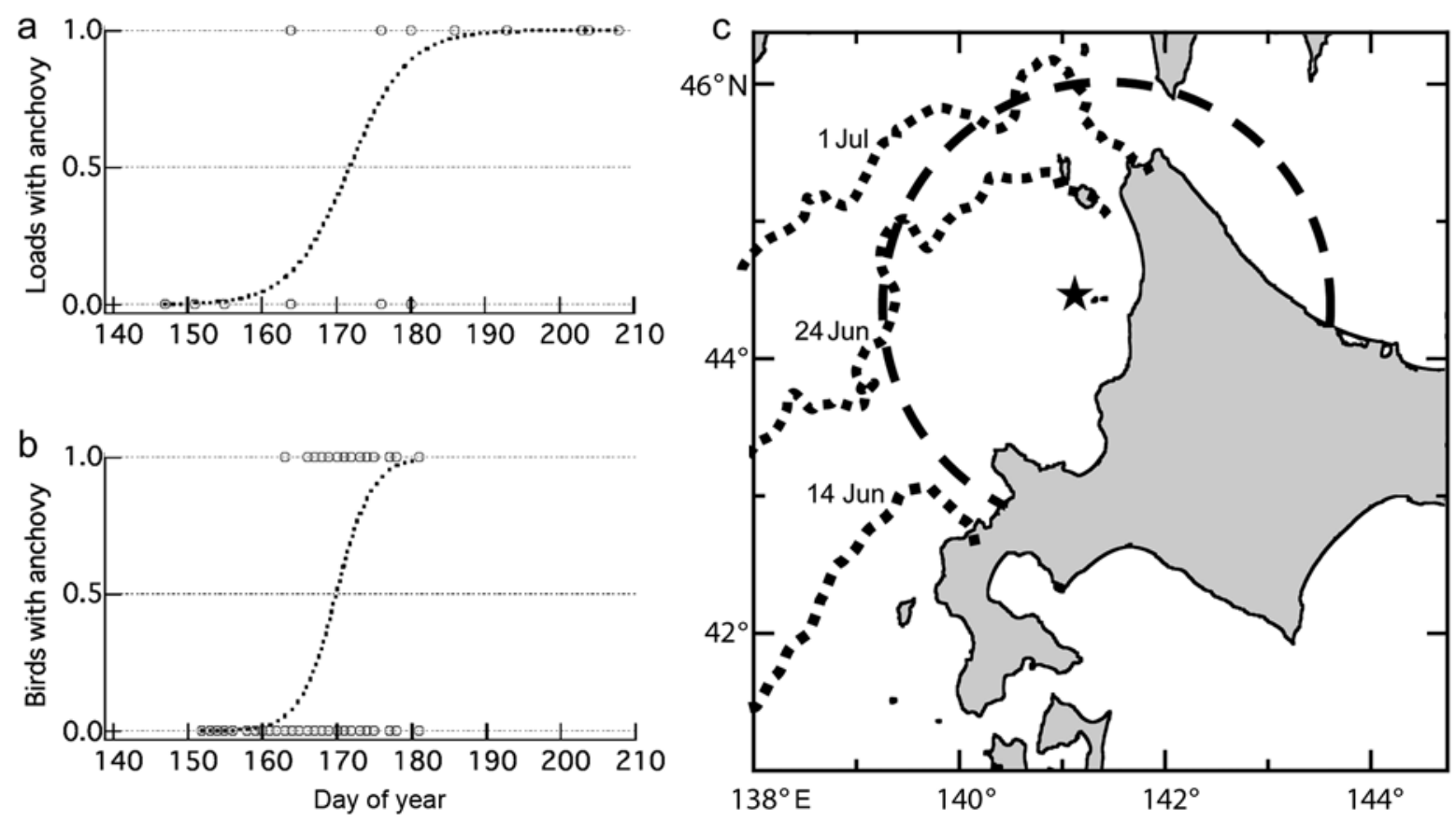

Fig. 2. Seasonal changes in (a) the occurrence of food loads with (designated as 1 ) and without (designated as 0 ) anchovy (n $=85$ food loads), and (b) birds carrying anchovy (1) or other fish (0) ( $\mathrm{n}=787$ birds) in 2006. Symbols for multiple samples on the same day overlap. Significant logistic regression lines are shown as broken lines. (c) The seasonal northern expansion of the $13^{\circ} \mathrm{C}$ SST (dotted lines with dates) in 2006 and the potential foraging range of auklets (broken line). Star indicates Teuri Island

Using data from 5 birds collected in 2006 and excluding dive bouts with fewer than 10 dives, the SST of waters where rhinoceros auklets fed on age- 0 sandlance (8 bouts) varied between 11.8 and $14.4^{\circ} \mathrm{C}$, and SST where they fed on age- 0 greenling ( 6 bouts) varied between $8.0^{\circ} \mathrm{C}$ and $13.7^{\circ} \mathrm{C}$. The SST where they fed on herring ( 2 bouts) was less than $11.6^{\circ} \mathrm{C}$, whereas that where they fed on anchovy ( 6 bouts) was higher than $13^{\circ} \mathrm{C}$. In the fishery off eastern Hokkaido, anchovy are harvested in relatively warm waters with an SST of 12 to $15^{\circ} \mathrm{C}$ (Mihara 1998). Thus, we inferred that anchovy expand their distribution northward as waters of $\sim 13^{\circ} \mathrm{C} \mathrm{SST}$ move northward with the northern expansion of the Tsushima Current.

Using the flight time determined by measuring acceleration with a bird-borne data-logger, and assuming flight speed to be $18 \mathrm{~m} \mathrm{~s}^{-1}$ and feeding frequency to be once per night, we estimated the average foraging ambit of rhinoceros auklets at Teuri Island to be $87 \mathrm{~km}$ with a maximum of $164 \mathrm{~km}$ (Kato et al. 2003; Fig. 2c). In 2006, the auklets switched their prey to anchovy between 18 and 21 June (Fig. 2a,b) when the northern limit of the $13^{\circ} \mathrm{C} \mathrm{SST}$ crossed the maximum foraging range (164 km; Fig. 2c). Therefore, we used the date when the SST of waters near the southern edge of the maximum foraging range of the auklets became higher than $13^{\circ} \mathrm{C}$ as the critical factor determining SWITCH.
Local climate and anchovy stock size. To examine the effects of local climate on the mean hatching date between years (HATCH, day of year), we used monthly mean air temperature (AIRTEMP) and total precipitation (RAIN) at Yagishiri Island $(4 \mathrm{~km}$ west of Teuri Island) and total snowfall (SNOW) at the nearest weather station in Haboro (30 km west of Teuri Island) in March (Japan Meteorological Agency, JMA, www. data.jma.go.jp/). For ocean climate, we used monthly mean SSTs in the northeastern and the southeastern coastal area of northern Hokkaido (stipped area in Fig. 1, LSST). We used the Merged Satellite and In Situ Data Global Daily SST (MGDSST), which is based on SST data collected by the AVHRR sensor on NOAA and Multi-functional Transport Satellite (MTSAT) satellites, reported by Hakodate Kaiyou Kishodai from 1985 to the present, to estimate SST in these regions (www.data.kishou.go.jp, in Japanese).

We used the daily mean SST in the coastal area off southern Hokkaido (hatched area in Fig. 1) to determine when warm waters of the Tsushima Current arrived in the study area. The date when the SST in this area exceeded $13^{\circ} \mathrm{C}$ was defined as the date that warm water arrived in the birds' foraging habitat $(W A R M A R R)$. The index of the flow rate of the Tsushima Current in the Japan Sea (FLOW; area of water at $100 \mathrm{~m}$ depth having temperatures higher than $10^{\circ} \mathrm{C}$ ) was obtained from the JMA (www.data.kishou. 
go.jp/kaiyou/shindan/e_2/maizuru_tsushima/maizuru_ tsushima.html, in Japanese).

The Tsushima anchovy stock is distributed from the west coast of Kyusyu to the Japan Sea coast of northern Japan, and should be available to rhinoceros auklets at Teuri Island in the summer. The stock size (ENGSTOCK) has been estimated annually since 1991 by monthly cohort analysis, and its trend has been validated by local acoustic surveys (Fisheries Agency http://abchan.job.affrc.go.jp/, in Japanese).

Statistical analyses. We used path analysis to identify the local climate factors explaining variation in mean hatch date $(\mathrm{HATCH})$, the date of prey-switching to anchovy (SWITCH), the proportional mass of anchovy in the diet (ENGDIET), and chick growth (GROWTH), fledgling mass (MASS), and the number of fledglings per nest with chicks (FLEDGLING) (Amos 6.0, Amos Development Corporation). We only used years where values of all independent factors were collected. Path analysis was selected in order to test direct and co-varying effects of independent variables. In addition to local climate factors, year (YEAR) was included as a potential independent factor to look at trends. To make the analyses simple, indirect effects were not included. The model giving the smallest value of the 0 -adjusted Akaike Information Criterion $\left(\mathrm{AIC}_{0}=0\right)$ was selected as the best-fitting model; the top 5 models with $\mathrm{AIC}_{0}<2.0$ are shown in 'Results (see Tables 1 \& 2) as these are believed to be appropriate models (Burnham \& Anderson 1998). Following Frederiksen et al. (2004), we also examined whether the slopes of factors were significant.

To find factors determining $H A T C H$, the model included AIRTEMP, LSST, SNOW, and RAIN in March, and YEAR ( $\mathrm{n}=17 \mathrm{yr}$, as LSST was not available in 1984). There were significant correlations between AIRTEMP and LSST ( $\mathrm{r}=0.601, \mathrm{p}<0.05)$ and between AIRTEMP and SNOW ( $\mathrm{r}=-0.519, \mathrm{p}<0.05$, Fig. 3a). Thus the model also included covariance between these. We found no significant correlations between other combinations of independent variables (SNOW, $R A I N, Y E A R ; \mathrm{r}=-0.08$ to $+0.33, \mathrm{p}>0.05)$.

$W A R M A R R$, the index of Tsushima Current flow in June (FLOW) when SWITCH mainly occurred (Fig. 3b,d), LSST in June, ENGSTOCK, and YEAR (n = 11) were candidate factors determining SWITCH; SWITCH was not defined in 7 years. We found significant correlations between WARMARR and FLOW ( $\mathrm{r}=-0.837, \mathrm{p}<0.001$, see Fig. 3b), WARMARR and LSST ( $\mathrm{r}=-0.787, \mathrm{p}<0.01)$, and FLOW and LSST $(\mathrm{r}=0.791, \mathrm{p}<0.01)$. It is obvious that strong Tsushima Current flow results in both a higher SST and the earlier arrival of warm $13^{\circ} \mathrm{C}$ water. Therefore, the model included WARMARR as the most proximate factor instead of FLOW or LSST. ENGSTOCK and YEAR were also included as independent factors. Since there were no significant correlations among these independent factors ( $r=-0.321$ to $0.065, p>0.05$, see Fig. $3 b, c)$, no covariance was included.

To find factors affecting ENGDIET, the model included degree of mismatch (MISMATCH), ENGSTOCK, and $Y E A R$ as independent variables. MISMATCH was defined as the difference between hatch date and date of prey-switching to anchovy, i.e. SWITCH - HATCH. Since there were no significant correlations among these independent factors ( $r=-0.370$ to 0.192 , NS), no covariance was included.

Last, effects of ENGDIET on GROWTH, MASS, and FLEDGLINGS were examined with AIRTEMP and $R A I N$ in June and YEAR included as independent factors ( $\mathrm{n}=18$ years). Covariance between ENGDIET and $Y E A R$ was positive and significant $(\mathrm{r}=0.776, \mathrm{p}<0.01)$, meaning that the auklets fed more on anchovy in later years, and was included in the model.

Atmospheric pressure and local climate. To investigate how large-scale climate affects $H A T C H$ and SWITCH, we constructed a correlation map of the monthly surface pressure in the Northern Hemisphere, based on NCEP/NCAR Reanalysis data (NOAA/OAR/ ESRL PSD; Kalnay et al. 1996) against the local climate factors most strongly affecting HATCH and SWITCH; the time series used information from 1984 to 2006 (1986 and 1988-1991 were excluded). We used local climate data from 1950 to 2007 to confirm results.

\section{RESULTS}

\section{Hatch date}

HATCH varied between 16 May and 6 June (Fig. 3d). In 4 out of 5 appropriate models, AIRTEMP in March had a significant effect on HATCH (Table 1). The slope of AIRTEMP on HATCH was negative, meaning that the auklets advanced hatching date by 3.7 to $4.9 \mathrm{~d}$ per $1^{\circ} \mathrm{C}$ increase in AIRTEMP (Table 1, Fig. 4). The first hatch date was similarly advanced as AIRTEMP increased (Fig. 4). The marginally significant positive slope of YEAR on HATCH indicates that HATCH was delayed slightly (0.32 to $\left.0.4 \mathrm{~d} \mathrm{yr}^{-1}\right)$ across years. SNOW, RAIN, and LSST in March had no significant direct effects.

\section{Date of prey-switching}

Rhinoceros auklets fed on sardine Sardinops melanostictus and sandlance and did not feed chicks with anchovy in 1984, 1985, or 1987, and rarely in 1992 (Fig. 3c). In 1994, 2003 and 2004, birds were already 
bringing back anchovy at the beginning of hatching and fed mostly on anchovy after that, so we did not find any significant logistic regressions. Thus, SWITCH was not determined in these years (see Fig. 3d). Excluding these years, SWITCH varied between 21 April and 31 July (Fig. 3d; n = 11 years).

All appropriate models included WARMARR as a significant factor (Table 1). The positive slope of WAR$M A R R$ on SWITCH indicates that the auklets delayed SWITCH by $3.3 \mathrm{~d}$ per day of delayed $13^{\circ} \mathrm{C}$ water (Table 1 , Fig. 5). YEAR was included as a factor in the best-fitting model. The marginally significant and negative slope of $Y E A R$ on SWITCH indicates that SWITCH was advanced by $1.1 \mathrm{~d} \mathrm{yr}^{-1}$ over the time series (Table 1). ENGSTOCK had no significant effects.

\section{Mismatch between $\mathrm{HATCH}$ and SWITCH}

ENGDIET varied between 1 and $94 \%$ during 1984 to 2006 (Fig. 3c). Using data of 11 years when SWITCH was determined, all 3 models included MISMATCH as a significant factor (Table 1). The negative slope of MIS-

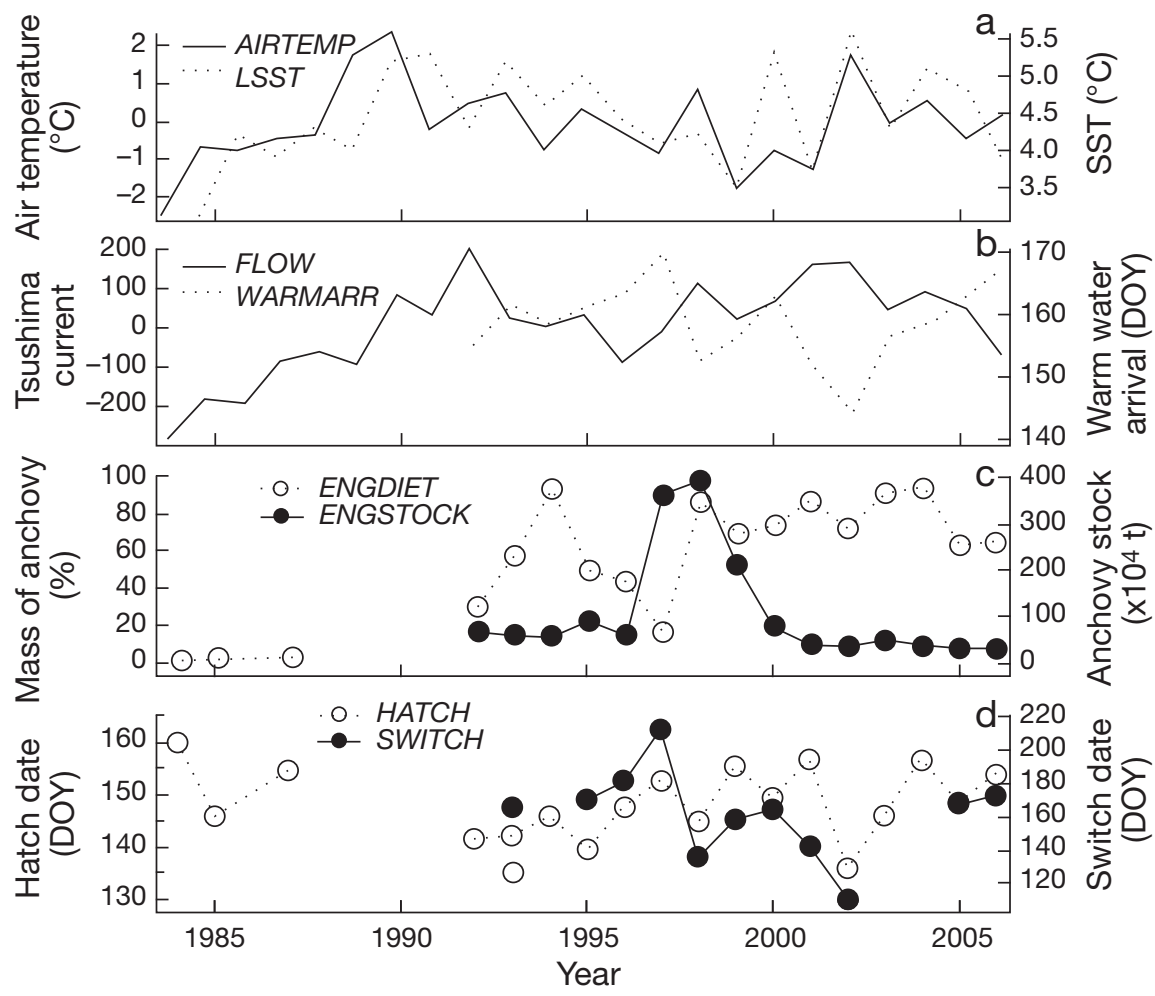

Fig. 3. Cerorhinca monocerata. Interannual changes in local climate factors and responses of rhinoceros auklets. (a) Mean monthly air temperature (AIRTEMP) in March at Yagishiri Island ( $3 \mathrm{~km}$ west of the colony), which was defined as the colony air temperature, and local monthly mean SST in March (LSST, see Fig. 1). (b) Flow rate index of the Tsushima Current (deviation from 1971-2000 average shown as \% of SD) in the Japan Sea (FLOW) in June and the date of the arrival of warm $\left(13^{\circ} \mathrm{C}\right)$ water at the southern edge of the potential foraging range of the auklets (WARMARR). (c) Size of the Tsushima anchovy stock (ENGSTOCK) and mass proportion of anchovy in food loads (ENGDIET). (d) Mean hatch date

$(H A T C H)$ and date of prey switching to anchovy (SWITCH). DOY: day of year

Table 1. Cerorhinca monocerata. Summary of the fitted path models relating hatch date (HATCH, day of year) to monthly mean air temperature in March $\left(A I R T E M P,{ }^{\circ} \mathrm{C}\right)$, total snow fall in March $(S N O W, \mathrm{~cm})$, total precipitation in March (RAIN, mm), and mean monthly local sea surface temperature in March $\left(L S S T,{ }^{\circ} \mathrm{C}\right)$; those relating the date of prey switching to anchovy $\left(S W I T C H\right.$, day of year) to the date of arrival of $13^{\circ} \mathrm{C}$ water within the birds' foraging range (WARMARR, day of year), and the stock size of anchovy (ENGSTOCK, $10^{4} \mathrm{t}$ ); and those relating the mass proportion of anchovy in the auklet diet (ENGDIET, \%) to the degree of mismatch between HATCH and SWITCH (MISMATCH, d) and ENGSTOCK. YEAR is also included as a factor. The 0 -adjusted AIC $\left(\mathrm{AIC}_{0}\right)$, the coefficent (SE, significance level), and the coefficient of determination $\left(\mathrm{R}^{2}\right)$ are shown. For HATCH, the covariance between AIRTEMP and LSST $(\mathrm{r}=0.601, \mathrm{p}<0.05)$ and bewteen AIRTEMP and SNOW $(\mathrm{r}=$ $-0.515, \mathrm{p}<0.05)$ are significant and are included in all models. For SWITCH and ENGDIET, covariance between WARMARR, ENGSTOCK, and YEAR or between MISMATCH, ENGSTOCK, and YEAR are not significant. Models having $\mathrm{AIC}_{0}<2.0$ but up to the fifth-best model are shown

\begin{tabular}{|c|c|c|c|c|c|c|c|}
\hline \multicolumn{2}{|l|}{ Dependent } & & & \multicolumn{3}{|c|}{ - Independent } & $\mathrm{R}^{2}$ \\
\hline \multirow[t]{6}{*}{ HATCH } & $\mathrm{AIC}_{0}$ & $Y E A R$ & AIRTEMP & SNOW & \multirow{6}{*}{$0.058(0.122,0.478)$} & $L S S T$ & \\
\hline & 0.000 & $0.319(0.178,0.073)$ & $-4.916(1.239,<0.001)$ & & & & 0.542 \\
\hline & 0.304 & $0.396(0.169,0.019)$ & $-3.735(1.467,<0.001)$ & & & $-2.605(1.841,0.157)$ & 0.615 \\
\hline & 0.890 & & $-4.648(1.356,<0.001)$ & & & & 0.423 \\
\hline & 1.775 & $0.318(0.177,0.072)$ & $-4.866(1.231,<0.001)$ & & & & 0.544 \\
\hline & 1.881 & $0.344(0.166,0.038)$ & $-2.828(1.885,0.133)$ & $0.028(0.036,0.434)$ & & $-3.132(2.028,0.122)$ & 0.609 \\
\hline \multirow[t]{5}{*}{ SWITCH } & $\mathrm{AIC}_{0}$ & $Y E A R$ & WARMARR & ENGSTOCK & & & \\
\hline & 0.000 & $-1.087(0.603,0.072)$ & $3.270(0.329,<0.001)$ & & & & 0.911 \\
\hline & 0.527 & & $3.292(0.337,<0.001)$ & $0.030(0.019,0.110)$ & & & 0.907 \\
\hline & 0.644 & $-0.859(0.563,0.127)$ & $3.257(0.307,<0.001)$ & $0.022(0.017,0.203)$ & & & 0.921 \\
\hline & 0.790 & & $3.327(0.378,<0.001)$ & & & & 0.886 \\
\hline \multirow[t]{4}{*}{ ENGDIET } & $\mathrm{AIC}_{0}$ & $Y E A R$ & MISMATCH & ENGSTOCK & & & \\
\hline & 0.000 & & $-0.754(0.166,<0.001)$ & & & & 0.808 \\
\hline & 1.847 & $0.294(0.694,0.672)$ & $-0.736(0.115,<0.001)$ & & & & 0.804 \\
\hline & 1.891 & & $-0.747(0.116,<0.001)$ & $-0.007(0.021,0.736)$ & & & 0.807 \\
\hline
\end{tabular}




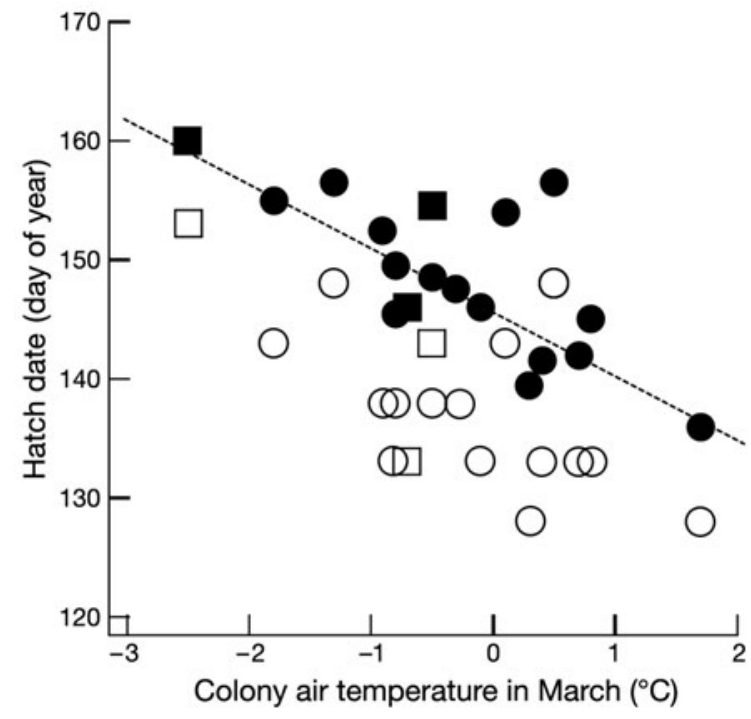

Fig. 4. Cerorhinca monocerata. Relationships of air temperature in March at the colony (AIRTEMP) with the mean hatch date $\left(\mathrm{HATCH}_{\text {; }}\right.$ closed symbols), and with the first hatch date (open symbols). Circles are data from 1992 to 2006 (15 yr), when auklets fed mainly on anchovy, and squares are data from 1984 to 1985 and 1987 ( 3 yr), when auklets rarely fed on anchovy. The broken line is the significant linear regression line of HATCH on AIRTEMP to show the trend

MATCH on ENGDIET indicates that as the degree of mismatch increased, the auklets fed less on anchovy (Fig. 6), because in years when the hatch date was earlier and the date of prey switching to anchovy was later, anchovy were available to the auklets for a shorter part of the chick-rearing period. The effect of YEAR was positive, but not significant, and ENGSTOCK had no effect (Table 1).

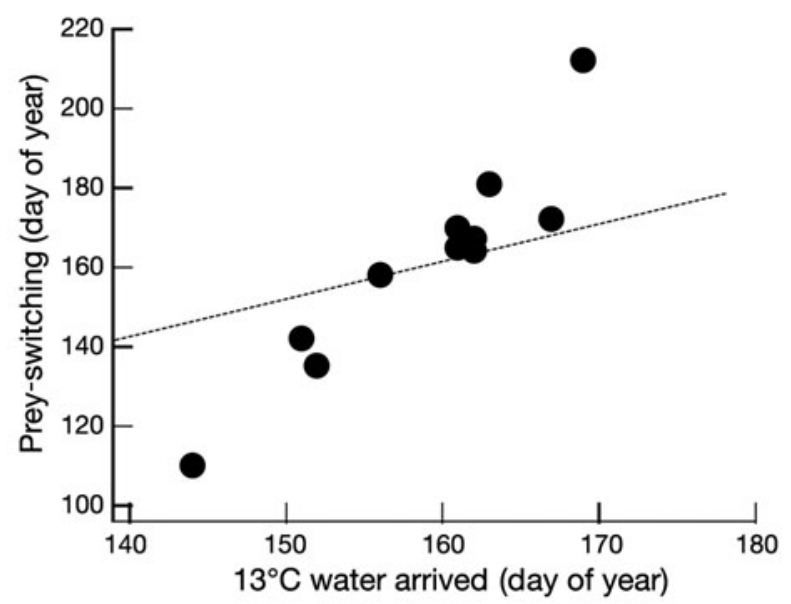

Fig. 5. Cerorhinca monocerata. Relationship between the date of the arrival of the $13^{\circ} \mathrm{C}$ water at the southern edge of the foraging range of the auklets from the colony (WARMARR) and the date of prey-switching to anchovy (SWITCH). Only data from years when $S W I T C H$ was determined $(\mathrm{n}=11)$ are shown. The broken line shows the 1 -to-1 relationship $($ slope $=1$ )

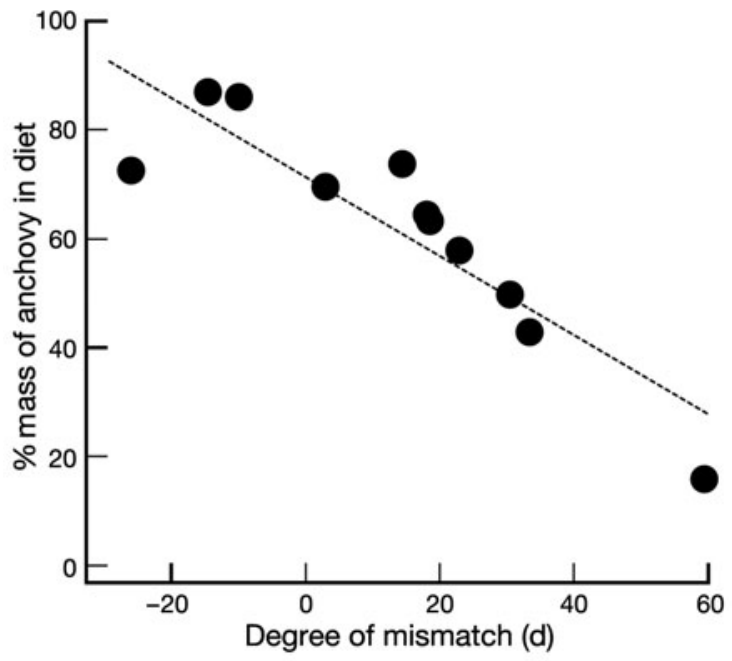

Fig. 6. Cerorhinca monocerata. Relationship between the number of days of mismatch (MISMATCH; difference between hatch date and date of prey-switching to anchovy, i.e. $S W I T C H-H A T C H$ ) and the mass proportion of anchovy in the chick diet (ENGDIET). Only data from years when SWITCH was determined $(\mathrm{n}=11)$ are shown. The broken line is the significant linear regression to show the trend

\section{Global surface pressure and local climate}

AIRTEMP in March, which mainly determined

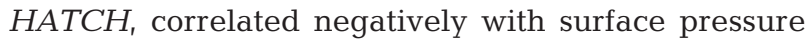
in March over the Arctic Sea and northern Eurasia, whereas the correlation was positive in areas surrounding the Arctic (Fig. 7a). This indicates that in years when pressure in the Arctic Sea and northern Eurasia was low, AIRTEMP was high. WARMARR, which determined SWITCH, was negatively correlated with the winter (December to February) surface pressure in the North Pacific east of Japan (Fig. 7c). Thus, in years when surface pressure in the North Pacific east of Japan was high in winter, the warm water arrived in the foraging range earlier in the season.

To extend the time series of local climate, we used surface air temperature (NECP/NCAR Reanalysis data) in March at the grid point nearest to the colony instead of AIRTEMP in March $\left(\mathrm{r}^{2}=0.627\right)$. WAR$M A R R$ was most strongly correlated with SST anomalies in the southwestern Japan Sea $\left(35-40^{\circ} \mathrm{N}\right.$, $\left.130-135^{\circ} \mathrm{E}\right)$ in April and May $\left(\mathrm{r}^{2}=0.422\right)$. When a longer time-series (1950 to 2007) is used, the correlation maps of pressure with local climate factors show similar patterns. When the March surface pressure in the Arctic was high, the air temperature in the grid nearest to the colony in March was lower (Fig. 7b). When the winter (December to February) pressure in the North Pacific east of Japan was higher, the April-May SST in the southwestern Japan Sea was also high (Fig. 7d). 

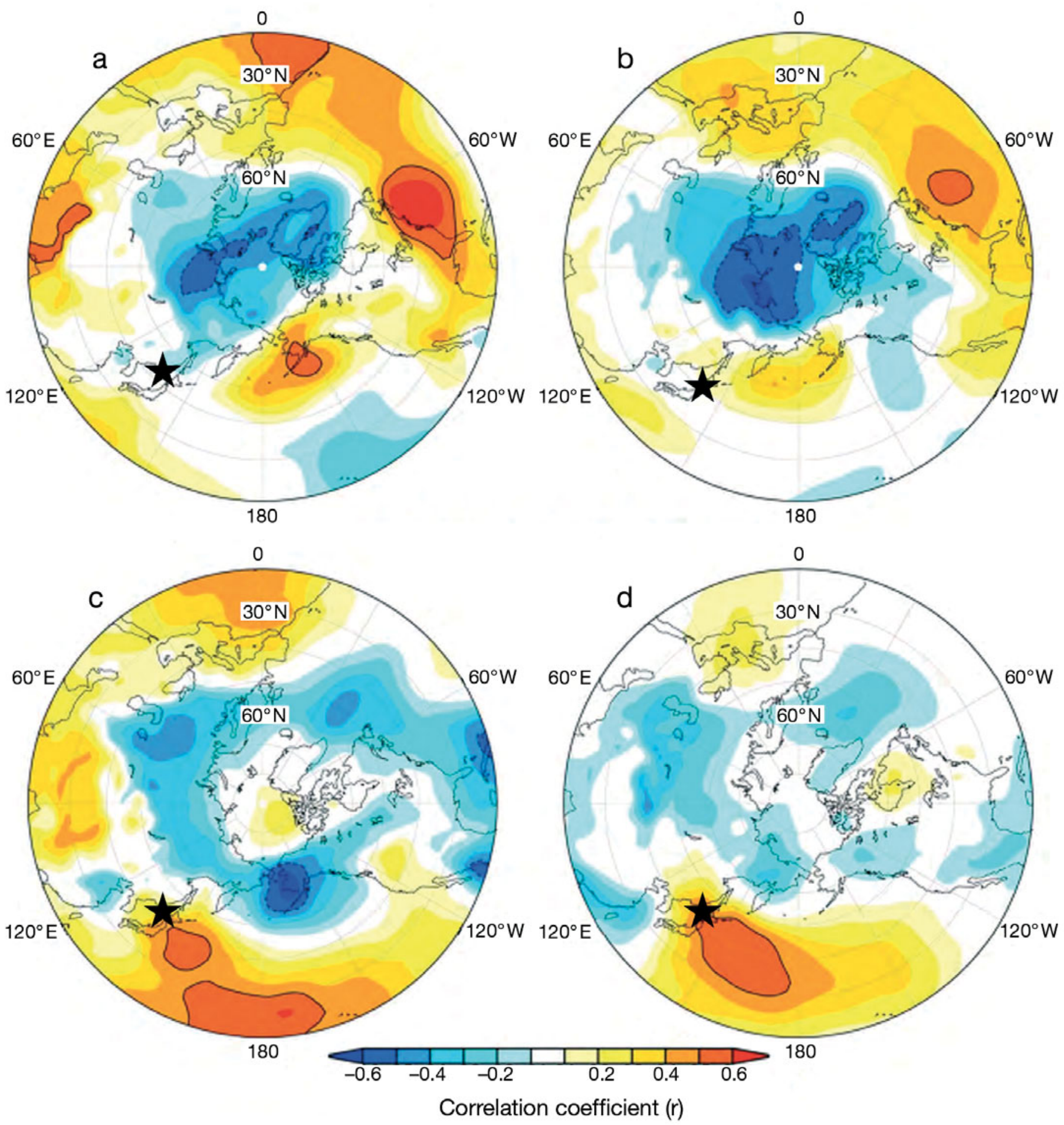

Fig. 7. Correlation maps (a) between March air temperature at the colony (AIRTEMP, which determined the hatch date) and March surface pressure (SP) in the Northern Hemisphere, and (c) between the minus date of the arrival of the $13^{\circ} \mathrm{C} \mathrm{SST}$ water at the southern edge of the foraging range of the rhinoceros auklets (WARMARR, which determined the date of prey-switching) and winter (December to February) SP in the Northern Hemisphere, based on local climate data collected during the study period. Note that the sign is negative in panel (c). Correlation maps based on longer time series of local climate data (NCEP-NCAR reanalysis data; 1950 to 2007) between (b) the March air temperature at the grid point nearest to the colony and the March SP, and (d) between the SST averaged over the southwestern Japan Sea from April to May and the winter (December to February) SPI. A color contour interval of 0.1 is used for the simple product-moment correlation coefficient (r). The star shows the position of the colony 
Table 2. Cerorhinca monocerata. Summary of the fitted path models relating the chick growth rate (GROWTH, $\mathrm{g}$ per $5 \mathrm{~d})$, the fledgling mass $(M A S S, g)$, and the number of fledglings per nest (FLEDGLING) to the proportional mass of anchovy in the chick $\operatorname{diet}(E N G D I E T, \%)$, mean air temperature in June $\left(A I R T E M P,{ }^{\circ} \mathrm{C}\right)$, and total precipitation in June $(R A I N, \mathrm{~mm})$. YEAR is also included as a factor. The covariance between YEAR and ENGDIET $(\mathrm{r}=0.776, \mathrm{p}<0.01)$ is significant and positive and is therefore included in the model. The covariances among other factors are not significant. The 0 -adjusted AIC(AIC $)_{0}$, the coefficent $\left(\mathrm{SE}_{\text {, }}\right.$ significance level), and the coefficient of determination $\left(\mathrm{R}^{2}\right)$ are shown. Models having $\mathrm{AIC}_{0}<2.0$ are shown

\begin{tabular}{|c|c|c|c|c|c|c|}
\hline \multirow{2}{*}{ Dependent } & \multirow{2}{*}{$\mathrm{AIC}_{0}$} & \multicolumn{4}{|c|}{ - Independent } & \multirow{2}{*}{$\mathrm{R}^{2}$} \\
\hline & & $Y E A R$ & ENGDIET & AIRTEMP & $R A I N$ & \\
\hline \multirow[t]{3}{*}{ GROWTH } & 0.000 & & $0.281(0.057,<0.001)$ & & $-0.270(0.079,<0.001)$ & 0.680 \\
\hline & 0.592 & $-0.537(0.426,0.207)$ & $0.358(0.087,<0.001)$ & & $-0.242(0.076,0.001)$ & 0.684 \\
\hline & 1.921 & & $0.284(0.057,<0.001)$ & $-0.610(2.130,0.774)$ & $-0.269(0.079,<0.001)$ & 0.684 \\
\hline \multirow[t]{4}{*}{ MASS } & 0.000 & & $1.623(0.305,<0.001)$ & & $-0.927(0.422,0.028)$ & 0.661 \\
\hline & 1.709 & & $1.373(0.340,<0.001)$ & & & 0.489 \\
\hline & 1.992 & $-0.217(2.379,0.927)$ & $1.654(0.484,<0.001)$ & & $-0.916(0.442,0.030)$ & 0.659 \\
\hline & 1.996 & & $1.619(0.305,<0.001)$ & $0.770(11.443,0.946)$ & $-0.928(0.422,0.028)$ & 0.666 \\
\hline \multirow[t]{2}{*}{ FLEDGLING } & 0.000 & & $0.004(0.001,<0.001)$ & $-0.085(0.039,0.031)$ & $-0.004(0.001,0.010)$ & 0.604 \\
\hline & 1.998 & & $0.004(0.001,0.002)$ & & $-0.004(0.002,0.018)$ & 0.467 \\
\hline
\end{tabular}

\section{Chick growth and fledging success}

In years when rhinoceros auklets fed chicks with more anchovy (ENGDIET), GROWTH, MASS, and FLEDGLINGS were greater (Table 2, Fig. 8a-c). RAIN in June had significant negative effects on each of these variables as well (Table 2). AIRTEMP in June had no significant effects on GROWTH and MASS but negatively affected FLEDGLINGS in the best-fitting model (Table 2).
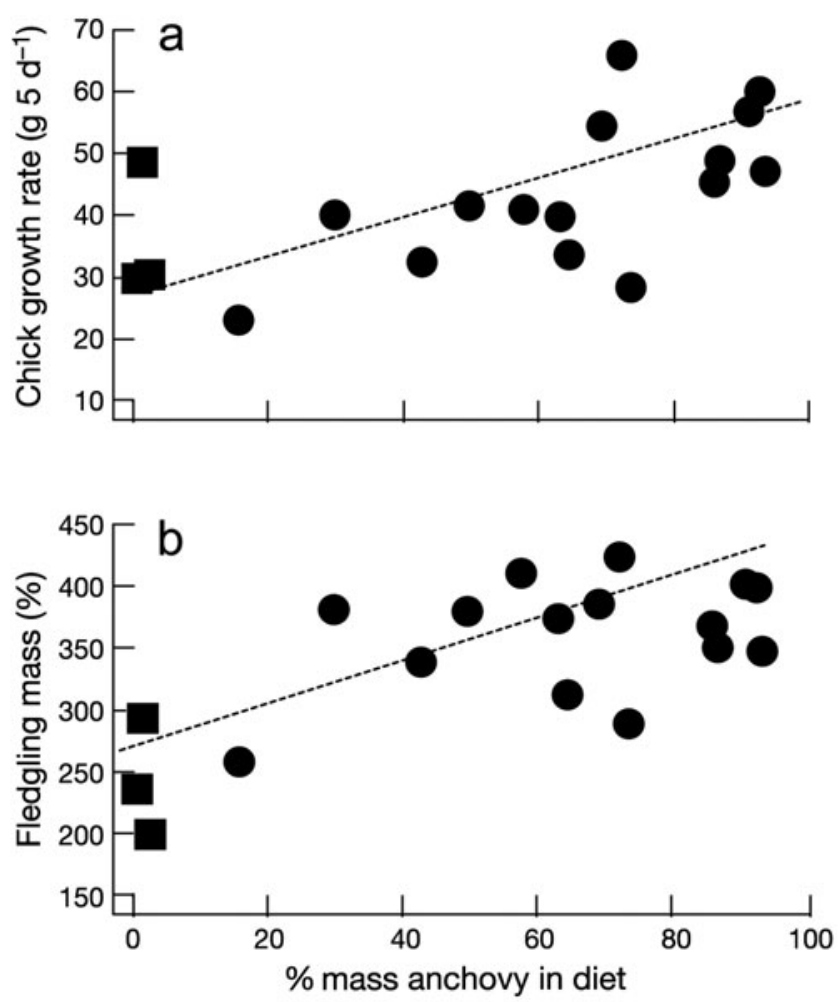

\section{DISCUSSION}

\section{Timing of breeding}

When the March air temperature was higher, hatching dates were earlier. According to the mean annual hatch date observed in this study (16 May to 6 June), and the reported incubation period for this species (39 to $52 \mathrm{~d}$, Gaston \& Jones 1998), the auklets laid eggs between late March and late April. Therefore, auklets

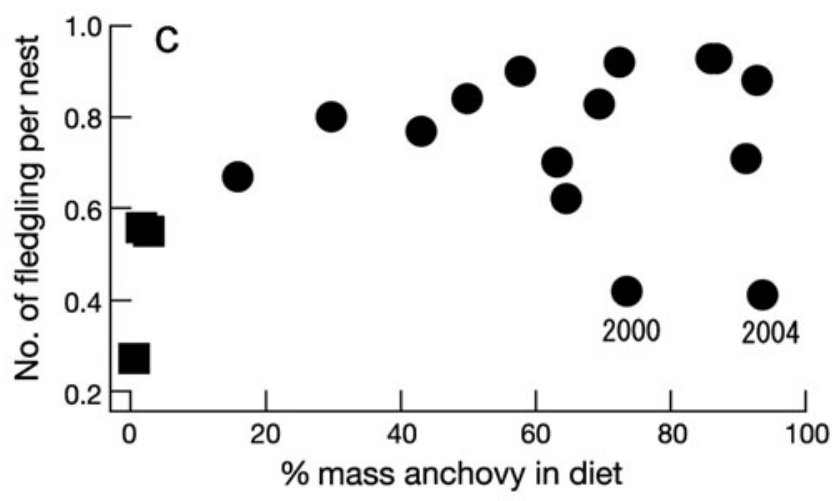

Fig. 8. Cerorhinca monocerata. (a) Relationship between the mass proportion of anchovy in the chick diet (ENGDIET) and mean chick growth rate (GROWTH), (b) mean fledgling mass (MASS), and (c) mean number of fledglings nest ${ }^{-1}$ (FLEDGLING). : data from 1992 to 2006, when auklets fed mainly on anchovy (15 yr); 口: data from 1984 to 1985 and 1987, when auklets rarely fed on anchovy ( 3 yr). Broken lines are significant simple linear regressions lines to show the trends for the 1984 to 2006 data 
started excavating burrows in March, and possibly earlier in February. In 1984, the auklets started egglaying in late April, which was 3 wk later than in 1985 (see Fig. 3d). As a result of lower spring air temperature (below freezing, see Fig. 3a) and the later disappearance of snow (mid-April) in 1984 than 1985, frozen soil in spring 1984 may have prevented the birds from excavating nest burrows (Watanuki 1987). Similarly, for prions Pachyptila desolata in the sub-Antarctic, hatching can be delayed if snow blocks their burrows in spring (Liddle 1994). Although total snowfall in March was negatively correlated with temperature in the Teuri region, snow did not influence hatching date directly.

Spring SST affects timing of breeding in several seabird species (Bertram et al. 2001, Gjerdrum et al. 2003, Frederiksen et al. 2004, Thayer \& Sydeman 2007), but wintertime conditions may also be influential (Schroeder et al. 2009). The covariance between air temperature near the colony (AIRTEMP) and SST around the colony (LSST) in March was significantly positive. LSST showed negative, though non-significant, effects on HATCH in the second- and fifth-best fitting models (Table 1). Therefore, a higher SST in spring might cause timing to be advanced. Rhinoceros auklets at Teuri Island feed on krill and fishes in the egg-laying season (Ito et al. 2009, this Theme Section). Thysanoessa inermis is the predominant krill species in coastal waters near Teuri Island (T. Deguchi pers. obs.). In spring, this species congregates to spawn at the sea surface off the western coast of Hokkaido when SST rises to $3-4^{\circ} \mathrm{C}$, and submerges when SST increases to $7-8^{\circ} \mathrm{C}$ (Hanamura et al. 1989). Thus, we cannot rule out the possibility that $L S S T$ in March, which ranged from 3.1 to $5.6^{\circ} \mathrm{C}$ (Fig. 3a) during the study years, affected the date of egg-laying through trophic effects.

\section{Timing of prey-switching}

Earlier arrival of warm waters at the southern edge of the auklets' foraging range (WARMARR), associated with the Tsushima Current, advanced the date of preyswitching to anchovy. Unexpectedly, the stock size of anchovy did not influence the date of prey-switching. The seasonal expansion of the distribution of anchovy was therefore more important than prey abundance in determining prey availability to the auklets. Similarly, the transport timing of herring Clupea harengus into the foraging range of Atlantic puffins Fratercula arctica in Norway was found to be the primary determinant of prey composition in that system (Durant et al. 2005).

However, it was not just the timing of arrival of warm waters that affected the take of anchovy by auklets in the Japan Sea. Overall, in years of generally warm SST, auklets switched to anchovy earlier than predicted by the Tsushima warm water arrival (Fig. 5). Flow rates and distribution of the Tsushima Current in the Japan Sea are complex and variable (Hase et al. 1999, Nakata \& Tanaka 2002). Variability in the meanders and eddies of the warm water mass along the coast of northern Japan (Naganuma 2000) might make anchovy locally available at small scales within the auklets foraging range earlier than predicted by the increase of mean surface temperature.

\section{Atmospheric pressure and degree of mismatch}

The spring air temperature, which determined hatching date, and the arrival of warm water within the foraging range, which determined the date of preyswitching, were each affected by different atmospheric pressure patterns. These patterns are not tightly linked, and hence can lead to a mismatch between the date of hatching and the date of prey-switching. When atmospheric pressure over the Arctic Sea and northern Eurasia is lower than normal and that over the northern Aleutian region is higher than normal (Arctic Oscillation; Thompson \& Wallace 1998), the eastern Asian winter monsoon is weakened, resulting in warming around the northern Japan Sea in proximity to the auklet colonies (Minobe et al. 2004), the southern Okhotsk Sea, and the northwestern North Pacific overall (Minobe \& Nakamura 2004). Higher air pressures over the Pacific Ocean east of Japan, which is associated with northward wind stress over the Tsushima Strait, may enhance the flow of the Tsushima Current in the Japan Sea (Minobe et al. 2004), thus causing an earlier northern expansion of anchovy.

Birds may adjust breeding dates so that they raise dependent offspring when prey availability is highest (Lack 1968). For example, tufted puffins Fratercula cirrhata in British Columbia breed later during cold years, which are less productive for their prey, in this case sandlance (Gjerdrum et al. 2003). This adjustment is possible if birds use environmental cues, such as climate signals during winter or spring, to 'predict' the timing of peak prey (Frederiksen et al. 2004). Rhinoceros auklets at Teuri Island were not able to adjust timing of breeding to match the date of anchovy arrival. Correlations between SST in March and warm water arrival date $(\mathrm{r}=-0.266, \mathrm{n}=16, \mathrm{NS})$ and between SST in March and SST in June $(r=0.326, n=17, N S)$ were weak, suggesting that environmental conditions early in the breeding season do not predict conditions later in the season. The long incubation period of the auklets coupled with this environmental unpredictability apparently makes adjustment of timing of breeding 
difficult. In addition, snow at Teuri Island makes it more difficult for the auklets to excavate burrows, a problem not encountered by tufted puffins in British Columbia, where the climate is milder (http://climate.weatheroffice.ec.gc.ca). Thus the auklets at Teuri Island are constrained in both burrow excavation and environmental sensitivity, and apparently cannot adjust their timing of breeding as well as related species in other locations.

\section{Long-term trends}

Rhinoceros auklets at Teuri Island fed on sardines, herring, and sandlance in the 1980s and mainly on anchovy in the 1990s and 2000s (Fig. 3c, Deguchi et al. 2004a). Accordingly, we found a positive correlation in the proportion of anchovy in the diet during the $18 \mathrm{yr}$ study period (Table 2). Effect of year on the date of prey switching was negative (Table 1). These time trends reflect a recruitment failure of sardine in 1988 to 1991, when a cold-to-warm regime shift occurred in the western Pacific (Watanabe et al. 1995), as well as an increase in the anchovy stock, which may be related to greater productivity or re-distribution.

Because of limited availability of data during the cold regime ( $3 \mathrm{yr} ; 1984$ to 1987), we cannot determine the relative importance of the effects of this regime shift versus inter-annual climate change. However, correlation maps of surface pressure in relation to the local climate factors that determined the hatching date based on 1950 to 2007 data show similar patterns to those observed during our study period. The effect of air temperature in March on hatching date during 1984 to 1987 seemed to be similar to that during 1992 to 2006 (Fig. 4). These results suggest that the surface pressure pattern may influence the onset of breeding similarly during both cold and warm regimes.

\section{Fitness consequences}

In years with high spring air temperatures and a weak Tsushima Current, the mismatch between the hatch date and the date of prey switching to anchovy was most pronounced, and the proportion of anchovy in the diet was smaller. When the auklets' food loads contain only anchovy, they are heavier than when they contain other fish species (Takahashi et al. 2001). As expected, in years when anchovy dominated the diet, food loads were heavier $\left(\mathrm{r}^{2}=0.417, \mathrm{n}=18\right.$ years, $\mathrm{p}=$ 0.004). However, the interannual variation in the energy density of food loads, calculated using published data (sardine, $10.5 \mathrm{~kJ} \mathrm{~g}^{-1}$ (in wet weight); anchovy, $6.3 \mathrm{~kJ} \mathrm{~g}^{-1}$; 0-year sandlance, $3.8 \mathrm{~kJ} \mathrm{~g}^{-1}$; 1-year sandlance, $5.5 \mathrm{~kJ} \mathrm{~g}^{-1}$; 0-year greenling, 4. $8 \mathrm{~kJ} \mathrm{~g}^{-1}$; herring, $5.8 \mathrm{~kJ} \mathrm{~g}^{-1}$; other fish, $5.0 \mathrm{~kJ} \mathrm{~g}^{-1}$; Watanuki 1992, Takahashi et al. 2001), was not related to the amount of anchovy in the diet $\left(\mathrm{r}^{2}=0.047, \mathrm{n}=18\right.$ years, not significant).

Thus, in years when anchovy was the primary prey species, auklets brought back heavier food loads, and chick growth rates, fledgling mass, and the number of fledglings produced increased. When 2 outlier years (2000 and 2004) were excluded, the effect of the proportion of anchovy in the diet on the number of fledglings was most apparent (Fig. 8c). Short-term food shortage, and/or prey that are too large during the early stage of chick development, might be critical to chick growth and survival and explain these outliers; this has been suggested for rhinoceros auklets in British Columbia (Vermeer 1980). In addition, precipitation in June negatively affected the number of fledglings (Table 2). Relatively high June precipitation in 2000 (114 mm) and 2004 (61 mm) compared to other years $(43 \pm 17 \mathrm{~mm}, 13-82 \mathrm{~mm})$ might also have lowered survival of chicks in these 2 years (Table 2 ). Thus the mismatch between the hatch date and the date of prey switching apparently affects population processes for rhinoceros auklets at Teuri Island through changes in growth, survival, and fledging mass of offspring.

The amplitude and direction of the effects of local climate on the reproductive success of rhinoceros auklets vary among regions. In British Columbia, rhinoceros auklets hatch earlier and chick growth and survival is lower in years with higher spring SST, presumably because warm spring conditions in this region favor an early peak in the zooplankton biomass, leading to a seasonal mismatch between zooplankton abundance and sandlance, the main prey given to auklet chicks (Bertram et al. 2001, Hedd et al. 2006). In contrast, in California, rhinoceros auklets start breeding earlier and have higher chick survival in years with lower SST, possibly because strong upwelling and cold-water conditions induce high primary and secondary productivity, including 1 of the auklets' main prey (juvenile rockfish, Sebastes spp.; Thayer \& Sydeman 2007). At Teuri Island, however, low spring air temperatures constrained the date of egg laying more strongly than spring SST, indicating that the physical nesting-ground conditions were more critical than trophic effects. There are no strong upwelling regions in the Japan Sea off Hokkaido (Naganuma 2000), so the transportation of anchovy via the Tsushima Current from the south in summer is the main mechanism determining the period of availability. Thus, local climate factors driven by different surface pressure patterns directly influence the seasonal mismatch of the auklets' hatching date, anchovy availability, and auk- 
let reproductive success. Local marine physical and biological systems should therefore result in local rhinoceros auklet populations having unique responses to climate change.

\section{CONCLUSION}

We have shown how large-scale atmospheric surface pressure affects local air temperature and flow rates of the warm Tsushima Current in the Japan Sea. In turn, variations in air temperature and the Tsushima Current can create a seasonal mismatch between the timing of breeding of rhinoceros auklets and the availability of their primary prey, anchovy, in our study region, with reproductive consequences. Such climate-mediated mechanisms vary among regions and populations. Therefore, local relationships must be analyzed and understood before changes in productivity relative to global climate changes can be predicted.

Acknowledgements. We thank A. Kato, Y. Niizuma, A. Takahashi, K. Iseki, M. Chochi, M. Kuroki, H. Ishikawa, T. Kagami, M. Takenaka, K. Matsumoto, D. Ochi, Y. Manabe, Y. Tanaka, N. Tomita, M. Takagi, H. Nomura, O. Hasegawa, T. Hirotsu, S. Hikosaka, and Y. Inoue for field assistance; M. Aotsuka and Y. Kusakabe for their hospitality on the island; and 3 anonymous referees and W. J. Sydeman for helpful and critical comments. Hakodate Kaiyou Kishodai provided SST data. This study was supported by Grants-in-Aid for Scientific Research (\#16108002 to M. Kishi, \#17370007 to Y.W.), and by the $21^{\text {st }}$ Century Centers of Excellence (COE) program 'Neo-Science of Natural History', led by H. Okada. The field work was carried out under permits from the Agency for Cultural Affairs and the Ministry of the Environment.

\section{LITERATURE CITED}

Abraham CL, Sydeman WJ (2004) Ocean climate, euphausiids and auklet nesting: inter-annual trends and variation in phenology, diet and growth of a planktivorous seabird, Ptychoramphus aleuticus. Mar Ecol Prog Ser 274:235-250

Amaoka K, Nakaya K, Yabe M (1995) The fishes of northern Japan. Kita Nippon Kaiyo Center, Sapporo (In Japanese)

Anderson PJ, Piatt JF (1999) Community reorganization in the Gulf of Alaska following ocean climate regime shift. Mar Ecol Prog Ser 189:117-123

Barbraud C, Weimerskirch H (2006) Antarctic birds breed later in response to climate change. Proc Natl Acad Sci USA 103:6248-6251

Bertram DF, Mackas DL, McKinnell SM (2001) The seasonal cycle revisited: interannual variation and ecosystem consequences. Prog Oceanogr 49:283-307

Both C, Bijlsma RG, Visser ME (2005) Climatic effects on timing of spring migration and breeding in a long-distance migrant, the pied flycatcher Ficedula hypoleuca. J Avian Biol 36:368-373

Both C, Bouwhuis S, Lessells CM, Visser ME (2006) Climate change and population declines in a long-distance migratory bird. Nature 441:81-83
Both C, van Asch M, Bijlsma RG, van den Burg AB, Visser ME (2009) Climate change and unequal phonological changes across four trophic levels: Constraints or adaptations? J Anim Ecol 78:73-83

Burnham KP, Anderson DR (1998) Model selection and inference: a practical information-theoretic approach. SpringerVerlag, New York, NY

Crick HQP, Dudley C, Glue DE, Thomson DL (1997) UK birds are laying eggs earlier. Nature 388:526

Deguchi T, Watanuki Y, Niizuma Y, Nakata A (2004a) Interannual variations of the occurrence of epipelagic fish in the diets of the seabirds breeding on Teuri Island, northern Hokkaido, Japan. Prog Oceanogr 61:267-275

> Deguchi T, Takahashi A, Watanuki Y (2004b) Proximate factors determining fledging age and mass in rhinoceros auklets: a study of within- and inter-year variations. Auk 121: 452-462

Drent $\mathrm{RH}$, Daan S (1980) The prudent parent: energetic adjustment in avian breeding. Ardea 68:225-252

Durant JM, Hjermann DØ, Anker-Nilssen T, Beaugrand G, Mysterud A, Pettorelli N, Stenseth NC (2005) Timing and abundance as key mechanisms affecting trophic interactions in variable environments. Ecol Lett 8:952-958

Durant JM, Anker-Nilssen T, Hjermann DO, Stenseth NC (2004) Regime shifts in the breeding of an Atlantic puffin population. Ecol Lett 7:388-394

$>$ Edwards M, Richardson AJ (2004) Impact of climate change on marine pelagic phenology and trophic mismatch. Nature 430:881-884

- Frederiksen M, Harris MP, Daunt F, Rothery P, Wanless S (2004) Scale-dependent climate signals drive breeding phenology of three seabird species. Glob Change Biol 10:1214-1221

Gaston T, Jones IL (1998) The Auks. Oxford University Press, Oxford

Gjerdrum C, Vallee AMJ, St. Clair CC, Bertram DF, Ryder JL, Blackburn GS (2003) Tufted puffin reproduction reveals ocean climate variability. Proc Natl Acad Sci USA 100: 9377-9382

Hanamura Y, Kotori M, Hamada S (1989) Daytime surface swarms of the euphausiid Tysanoessa inermis off the west coast of Hokkaido, northern Japan. Mar Biol 102:369-376

> Hase H, Yoon JH, Koterayama W (1999) The current structure of the Tsushima warm current along the Japanese coast. J Oceanogr 55:217-235

$>$ Hedd A, Bertram DF, Ryder JL, Jones IL (2006) Effects of interdecadal climate variability on marine trophic interactions: rhinoceros auklets and their fish prey. Mar Ecol Prog Ser 309:263-278

> Hipfner JM (2008) Matches and mismatches: ocean climate, prey phenology and breeding success in a zooplanktivorous seabird. Mar Ecol Prog Ser 368:295-304

> Hunt GL Jr, Stabeno PJ (2002) Climate change and the control of energy flow in the southeastern Bering Sea. Prog Oceanogr 55:5-22

Ito M, Minami H, Tanaka Y, Watanuki Y (2009) Seasonal and inter-annual oceanographic changes induce diet switching in a piscivorous seabird. Mar Ecol Prog Ser 393:273-284

Kalnay E, Kanamitsu M, Kistler R, Collins W and others (1996) The NCEP/NCAR 40-Year Reanalysis Project. Bull Am Meteorol Soc 77:437-472

Kato A, Watanuki Y, Naito Y (2003) Foraging behaviour of chick-rearing rhinoceros auklets at Teuri Island, Japan, determined by acceleration-depth recording micro data loggers. J Avian Biol 34:282-287

Kuroki M, Kato A, Watanuki Y, Takahashi A (1998) Artificial nest boxes for the study of breeding ecology of rhinoceros 
auklet Cerorhinca monocerata. J Yamashina Inst Ornithol 30:40-46 (in Japanese)

Kuroki M, Kato A, Watanuki Y, Niizuma Y, Takahashi A, Naito Y (2003) Diving behavior of an epipelagicallyfeeding alcid, the rhinoceros auklet (Cerorhinca monocerata). Can J Zool 81:1249-1256

Lack D (1968) Ecological adaptations for breeding in birds. Methuen, London

Liddle GM (1994) Interannual variation in the breeding biology of the Antarctic prion Pachyptila desolata at Bird Island. J Zool (Lond) 234:125-139

Mihara Y (1998) Distribution of the Japanese anchovy, Engraulis japonicus, off southeastern Hokkaido. Sci Rep Hokkaido Fish Exp Stn 53:9-14 (in Japanese with English abstract)

Minobe S, Nakamura M (2004) Interannual to decadal variability in the southern Okhotsk Sea based on a new gridded upper water temperature data set. J Geophys Res 109:C09S05. doi:10.1029/2003JC001916

Minobe S, Sako A, Nakamura M (2004) Interannual to interdecadal variability in the Japan Sea based on a new gridded upper water temperature dataset. J Phys Oceanogr $34: 2382-2397$

Naganuma K (2000) The Sea of Japan as the natural environment of marine organisms. Bull Jpn Sea Natl Fish Res Inst 50:1-42 (in Japanese)

Nakata A, Tanaka I (2002) Seasonal and year-to-year variability of baroclinic volume transport of the Tsushima Warm Current, off the west of Hokkaido. Sci Rep Hokkaido Fish Exp Stn 63:1-8 (in Japanese)

Platt T, Fuentes-Yaco C, Frank KT (2003) Spring algal bloom and larval fish survival. Nature 423:398-399

Schroeder ID, Sydeman WJ, Sarkar N, Thompson SA, Bograd SJ, Schwing FB (2009) Winter pre-conditioning of seabird phenology in the California Current. Mar Ecol Prog Ser 393:211-223

Stenseth NC, Mysterud A (2002) Climate, changing phenology, and other life history traits: nonlinear and matchmismatch to the environment. Proc Natl Acad Sci USA 99:13379-13381

Stenseth NC, Mysterud A, Ottersen G, Hurrell JW, Chan KS,

Submitted: October 29, 2008; Accepted: August 11, 2009
Lima M (2002) Ecological effects of climate fluctuations. Science 297:1292-1296

Takahashi A, Kuroki M, Niizuma Y, Kato A, Saito A, Watanuki Y (2001) Importance of the Japanese anchovy Engraulis japonicus to breeding rhinoceros auklets Cerorhinca monocerata on Teuri Island, Sea of Japan. Mar Biol 139:361-371

Thayer JA, Sydeman WJ (2007) Spatio-temporal variability in prey harvest and reproductive ecology of a piscivorous seabird, Cerorhinca monocerata, in an upwelling system. Mar Ecol Prog Ser 329:253-265

- Thayer JA, Bertram DF, Hatch SA, Hipfner MJ, Slater L, Sydeman WJ, Watanuki Y (2008) Forage fish of the Pacific Rim as revealed by diet of a piscivorous seabird: synchrony and relationships with sea surface temperature. Can J Fish Aquat Sci 65:1610-1622

Thompson DWJ, Wallace JM (1998) The Arctic Oscillation signature in the wintertime geopotential height and temperature fields. Geophys Res Lett 25:1297-1300

Vermeer K (1980) The importance of timing and type of prey to reproductive success of rhinoceros auklets Cerorhinca monocerata. Ibis 122:343-350

> Visser MF, Both C (2005) Shifts in phenology due to global climate change: the need for a yardstick. Proc R Soc Lond B Biol Sci 272:2561-2569

Visser ME, Adriaensen F, van Balen JH, Blondel J and others (2003) Variable responses to large-scale climate change in European Parus populations. Proc R Soc Lond B Biol Sci 270:367-372

- Watanabe Y, Zenitani H, Kimura R (1995) Population decline of the Japanese sardine Sardinops melanostictus owing to recruitment failures. Can J Fish Aquat Sci 52:1609-1616

Watanuki Y (1987) Breeding biology and foods of rhinoceros auklets on Teuri Island, Japan. Proc NIPR Symp Polar Biol 1:175-183

- Watanuki Y (1992) Individual diet difference, parental care and reproductive success in slaty-backed gulls. Condor 94:159-171

> Watanuki Y, Mehlum F, Takahashi A (2001) Water temperature sampling by foraging Brünnich's guillemots with bird-borne data loggers. J Avian Biol 32:189-193

Proofs received from author(s): October 5, 2009 